Revue bibliographique pour le domaine irano-aryen

\title{
Esmail Hemati Azandaryani, Hamid Khanali, Habibolah Rashidbeigi. "Tepe Golshan, A Parthian Cemetery in Western Iran"
}

\section{Leonardo Gregoratti}

\section{(2) OpenEdition Journals}

Electronic version

URL: http://journals.openedition.org/abstractairanica/46842

DOI: $10.4000 / a b s t r a c t a i r a n i c a .46842$

ISBN: 1961-960X

ISSN: 1961-960X

Publisher:

CNRS (UMR 7528 Mondes iraniens et indiens), Éditions de l'IFRI

\section{Electronic reference}

Leonardo Gregoratti, «Esmail Hemati Azandaryani, Hamid Khanali, Habibolah Rashidbeigi. "Tepe Golshan, A Parthian Cemetery in Western Iran" », Abstracta Iranica [Online], Volume 37-38-39 | 2018, document 52, Online since 30 December 2018, connection on 28 September 2020. URL : http:// journals.openedition.org/abstractairanica/46842; DOI : https://doi.org/10.4000/abstractairanica. 46842

This text was automatically generated on 28 September 2020 .

Tous droits réservés 


\title{
Esmail Hemati Azandaryani, Hamid Khanali, Habibolah Rashidbeigi. "Tepe Golshan, A Parthian Cemetery in Western Iran"
}

\author{
Leonardo Gregoratti
}

\section{REFERENCES}

Esmail Hemati Azandaryani, Hamid Khanali, Habibolah Rashidbeigi. “Tepe Golshan, A Parthian Cemetery in Western Iran", Parthica, 18, 2016, p. 53-63

1 The site of Tepe Golshan is located in western Iran, very close to Nahavand. In 1995, the archaeological excavation of this area led to the identification of a Parthian cemetery. A team of archaeologists discovered and excavated six burials there. Five of them are pits, a type of burial rather common in Iran in the Parthian period. The authors mention only few of the many sites where this kind of grave is attested: at Sange-Shir, close to Hamadan, at Sad-e Eskandar in the Gorgan plain, at Cheshmeh Sar, near Persepolis and in the necropolis of Germi in Iranian Azarbaijan. Much more interesting is the clay coffin found in the trench 3. It is a kind of coffin, which does not present any trace of glaze. Unglazed coffins are attested for Cheshmeh Sar, Bolehya and other cemeteries near Susa, Dastva, near Shoshtar and Kangavar, but the majority of similar burials has been found in the many burial spots in the area of the nearby Hamadan. With the exception of one skeleton, which was buried in a coffin, all the other human remains were found in graves without any cover. The burial orientation was on a north-south axis in all graves but those found in the so-called trench 8 , in which the head of the deceased were positioned towards to the south. 


\section{AUTHORS}

\section{LEONARDO GREGORATTI}

Durham University 